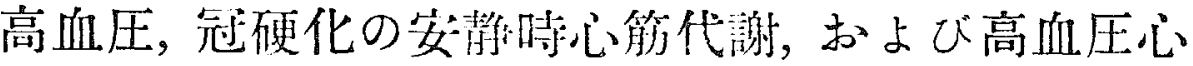 し筇代謝におよにす降圧剂の影響
}

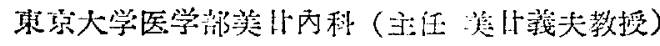 \\ 太田昭夫
}

\section{STUDIES ON MYOCARDIAL METABOLISM OF PATIENTS WITH HYPERTENSION AND WITH CORONARY SCLEROSIS IN RESTIONG STATE, AND EFFECTS OF ANTIHYPER. TENSIVE AGENTS ON MYOCARDIAL METABOLISM OF HYPERTENSIVES}

\author{
BY \\ Akio Ōta \\ (Medical Clinic of Prof. Mikamo, The University of Tokyo, Faculty of Medicine.)
}

Myocardial metabolism was studied on 39 patients with hypertension and 14 patients with coronary sclerosis by means of the coronary sinus catheterization. These patients were classified into the following three groups, according to the values of blcod pressure and ECG findings.

Group I : 13 cases. The average value of mean blood perssure measured $127 \mathrm{mmHg}$, and enlargement of left ventricle was observed in all the patients except for 2 cases.

Group II : 26 cases. Hypertensives that denote depressed ST, flat or inverted T wave, or the combination of these abnormalities on ECG. The average value of mean blood pressure measured $133 \mathrm{mmHg}$ in height. All patients except for 2 cases showed the enlargement of left ventricle, including 4 cases with marked enlargement.

Group III : 14 cases. Coronary sclerosis without hypertension. Mean blood pressure averaged $93 \mathrm{mmHg}$. Enlargement of left ventricle was noticed in 6 cases.

Following results thus obtained were compared with the normal data previously reported.

1) In group $\mathrm{I}$, myocardial $\mathrm{O}_{2}$ extraction and $\mathrm{O}_{2}$ extraction coefficient were normal, while myocardial lactate and pyruvate extraction coefficient ratios were decreased. These results indicate the disturbance of myocardial carbohydrate metabolism in this group.

2) In group II, abnormalities of myocardial gaseous and carbohydrate metabolism were remarkable; i. e., $\mathrm{O}_{2}$ extraciion coefficient was increased, myocardial $R Q$ was belcw normal, and in a few cases $\mathrm{O}_{2}$ partial pressure of coronary venous blood was decreased. Moreover, myocardial lactate and ryruvate extraction coeffecient ratios were reduced s gnificantly, and myocardial $\mathrm{O}_{2}$ extraction ratio as well. In addition, coronary venous

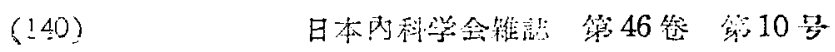


blood $\mathrm{pH}$ was measured on 12 of tha patients $\in \mathrm{X}$ umined and four of these showed increas $2 \mathrm{~d}$ coronary venous difference of $\mathrm{pH}$.

3) In group $\mathbb{I l}, \mathrm{O}_{2}$ extr ction and $\mathrm{O}_{2}$ extraction coefficient of cardiac muscle inclined to diminish, and markel reduction of $\mathrm{O}_{2}$ partial pressure of coronary venous blood was noticed in all 4 cases. Abno malities of myocurdial lactate and pyruvate metabolism were also observed in this group.

4) From the data above mentioned, it is inferred that myocardial hypoxia is the major cause of these metabolic disturbances, and that, in group I, contributing factor of the hypoxia was myocardial hypertrophy, and that in group $\mathbb{H}^{\prime}$, it is the relative limitation of coronary blood flow due to coronary sclerosis. Accordingly, group II, influenced by these two facters, exhibiled the most severe changes, and the myocardial metabolism got worse, parellel with the clinical grades of hypertension and ECG findings. In some cases of group IIl whose ECG were normal in resting state, the increase of myocardial $\mathrm{O}_{2}$ extraction coefficient was noticed. This suggests the existence of myocardial hypoxia in these cases.

5) Hexamethonium $\left(\mathrm{C}_{6}\right)$ and hydralazine $(\mathrm{Hy})$ were administered intravenously on ten hypertensive patients. $\mathrm{HY}$ decreased myocardial $\mathrm{O}_{2}$ extraction coefficient in all four cases, but $\mathrm{C}_{6}$ did in only two cases out of six examined. As to myocardial lactate nd pyruvate extraction coefficient ratios, $\mathrm{C}_{6}$ increased them. Some discussion concerning the different actions of these two agents on coroanry circulation were attempted.

䍃言

高血左症ならびに冠硬化症に特ける心筋代謝の

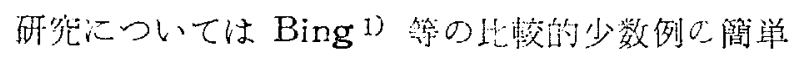
な報告があるに過ざない、したがつてこれら症例 に拈ける心筋代謝を追求し，㹂床所見々対比させ ることは極めて意救あることと思われる。

わが教室では1952 年以来人体における冠静脈 カテーテル法を実施し，1957年 7 月をでに浽功例 175 例に達したが，著者はその間, 計 53 例の高血 王心ならびに冠硬化心について安静時心筋代謝お よび降王剤の影犁について観祭し，いささかの新 知見を得たのでここに報告する。

\section{症例}

1957 年 7 月までに実験に成功した高血王および 过硬化の䃾例は会計 57 例であるが, その中から他

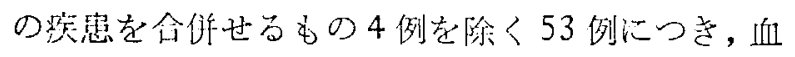
王および心電図所見に基づき次の3 群に分類した。
第 I 群 13 例 収維期血压 $150 \mathrm{mmH} \mathrm{g}$ 以上, または拉㖘期血压 $90 \mathrm{~m} \mathrm{nHg}$ 以上のもので，かつ 平均血正 $110 \mathrm{mmHg}$ 以上艺示し, 心電图上 $\mathrm{ST}$,

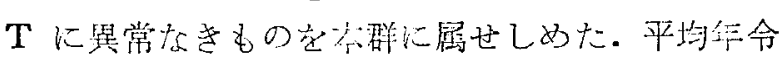

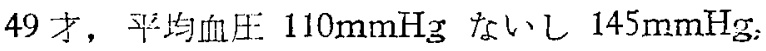
その平均综 $127 \mathrm{mmII}$ であつた。2 例を除さ心陰

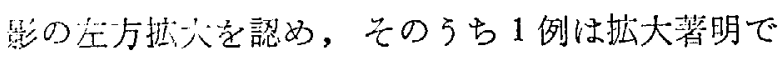
あつた。

第II 群 26 例 同じく高血圧症例であつて心電 図上 I III $\mathrm{aV}_{\mathrm{L}} \mathrm{aV}_{\mathrm{F}} \mathrm{V}_{4-6}$ の訜導で $\mathrm{ST}$ 低下, $\mathrm{T}$ の平低化，または这転を久るもの.5ち6例はST 低下 $0.5 \mathrm{~mm}$ 以内の軽度低下, または運動負荷に より ST 低下を示すもの (土群)，11 例は上記唀 導中 3 棌導以上で $1 \mathrm{~mm}$ 以上の低下を示例 (H 群)，残り9例は両者の中間に位する (十群). 定 型的のいわゆる肥大型を示した 1 例を除き $\mathrm{ST}, \mathrm{T}$ の所見は大部分, 冠不全型, 一部は闭型の中間を 示した，2例を除く全例に心陰影の左方扰大を認 


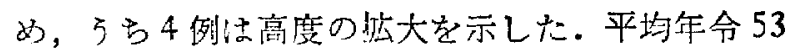
才, 平均血生 $112 \mathrm{mmHg}$ ない儿 $162 \mathrm{mmHg}$, そ の平均は $132 \mathrm{mmHg}$ であつた。

第直群 14 例 い种马冠硬化性心疾患嘱す るもので高血圧なく，8 例はST 低下を安静時に， 6 例は運動負荷後に示した。6 例に怙いて心陰影

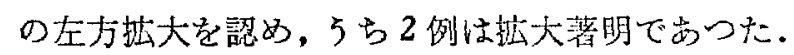
平均年令 53 才, 平圧血圧 $72 \mathrm{mmHg}$ ないし 106 $\mathrm{mmHg}$ ，矢の平均は $93 \mathrm{mmHg}$ でからた。

な招血止の測定はりバロッチ型血在計を用い右 上腕動脈で行なつた。政料との対比は採血直前, または採血中の测定值を橓るを通例上したが，少 数例についてはカランーテル捙入前の安静時血圧を 利用した。

\section{実験方法}

カテーテル捙入 カテーテルは一般のカォー テルと同様普通左肘静脈より拆入，X楾透視下に 冠静脈洞上り大心灆静脈内唀導寸るのである が，その奏施にかんしては，すでに発素2)したの で省略する，カテーテル扱人後は血圧が安定する まで放置し, 大体 30 分後, 被検者が安定状態见 なるのをまつてカテーテルを通じ冠静脈血を採取 し, 同時に大腿, または上腕動脈穿刺により体動 脈血を採取, 試料とした。

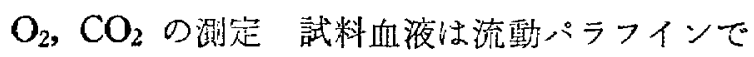
気密とした这射器内に採取, 筀氛との接触を避け て容器に移し，Van-Slyke-Neill の気王法によつ てそれぞれ $\mathrm{O}_{2} ， \mathrm{CO}_{2}$ 容量を測定した。これらの 測定值上り冠動静脈血 $\mathrm{O}_{2}$ 较美 $\left(\Delta \mathrm{O}_{2}\right)$ ，心筋 $\mathrm{O}_{2}$ 攝取率，心筋 $\mathrm{RQ}$ を計算，さらに $\mathrm{pH}$ を測定， これと Ht 值を㬨、Dill にしたがつて冠静脈血 $\mathrm{O}_{2}$ 分压を求め大。なお $\Delta \mathrm{O}_{2}$ は $0.5 \mathrm{Vol} \%$ 以上, $\mathrm{O}_{2}$ 攝取率は 0.03 以上の差を有意とした。

pH の測定 Cambridge のガラス霓極により測 定した．测定値の差は 0.01 以上をもつて有意とし た。

ブドウ糖の測定 大部分は Somogyi 法, 一部 は Hagedorn-Jansen 法によりて测定した。それ 外㧈の測定㑑の差は $2 \mathrm{mg} / \mathrm{dl}, 5 \mathrm{mg} / \mathrm{dl}$ 以上をる
つて有意とした。この测定值より冠動静脈血ブド ウ湷較差 ( $(G \mathrm{G})$ が得られ，李た Bingにならいブ ドウ綨 $\mathrm{O}_{2}$ 摄取率が算出される。

$$
\text { ブドウ䌅 } \mathrm{O}_{2} \text { 霞取菜 }=\frac{\Delta \mathrm{G} \times 0.75}{4 \mathrm{O}_{2}}(\%)
$$

乳酸の测定 Barker \& Summersonによる。 湖定誤差は土2\%。ブドウ粮と同㥞冠動静脈血乳

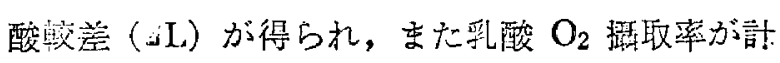
算される。

$$
\text { 乳酸 } \mathrm{O}_{2} \text { 勒取率 }=\frac{\Delta \mathrm{L} \times 0.75}{\Delta \mathrm{O}_{2}}(\%)
$$

乳㖶の心籍比よる嶵取は健常者において動脈血

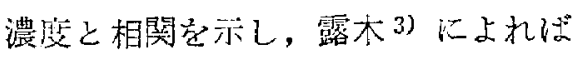

$$
\mathrm{La}=0.116 \mathrm{~A}^{2}+0.608 \Delta \mathrm{L}+3.15
$$

$\mathrm{La}$ ：動脈血乳酸浱度 $\mathrm{mg} / \mathrm{dl}$

で示される。

ま大㙫常および各群間の 動脈血乳酸濃度が一定

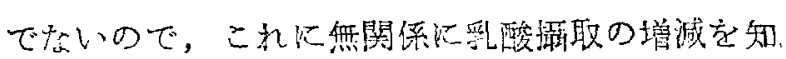
るた放乳酸攝取率比を求めた。

$$
\text { 乳酸攝取率比 }=-\frac{\Delta \mathrm{L}}{\mathrm{La}} / \frac{\Delta \mathrm{L}_{\mathrm{N}}}{\mathrm{La}}=\frac{\Delta \mathrm{L}}{\Delta \mathrm{L}_{\mathrm{N}}}(\%)
$$

$\Delta \mathrm{L}_{\mathrm{N}}$ ：健常者の乳酸較差 $(\mathrm{mg} / \mathrm{dl})$

ただし La が $4 \mathrm{mg} / \mathrm{dl}$ 以下では上記乳酸嗙差, 動脈血澧度曲楾が実際は一定の幅をるつてX㒹

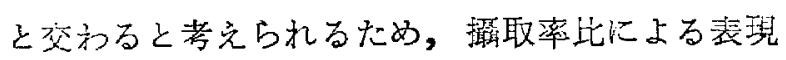
は出来ない。

焦性ブドウ酸（以下焦酸と略す）の測定 Friedmann \& Haugen 清水变法, 测定誤差は $\%$. 前 2 者と同椂焦酸较差 $(\Delta \mathrm{P})$ 和上び焦酸 $\mathrm{O}^{2}$ 攝取率が計算される。

$$
\text { 焦酸 } \mathrm{O}_{2} \text { 攝取率 }=\frac{\Delta \mathrm{P} \times 0.64}{\Delta \mathrm{O}_{2}}(\%)
$$

焦酸の心筋による攝取は隹常者において動脈血 滥度と相関を示し厚美4)に上れば

$$
\Delta \mathrm{P}=0.75 \mathrm{~Pa}-0.34
$$

$\mathrm{Pa}$ ：動脈血焦酸濃度 $\mathrm{mg} / \mathrm{dl}$

まさ乳酸と同じく動脈血湢度 $0.75 \mathrm{mg} / \mathrm{d} 1$ 以上 に斿いて焦酸攝取染比を算出し，健常および各群 閐の比警に用いた。 
焦酸攝取率 $=\frac{\Delta \mathrm{P}}{\mathrm{Pa}} / \frac{\Delta \mathrm{P}_{\mathrm{N}}}{\mathrm{Pa}_{-}}=\frac{\Delta \mathrm{P}}{\Delta \mathrm{P}_{\mathrm{N}}}(\%)$

成 樍

I安静時心筋代謝 (第 1,2,3 表)

$\mathrm{O}_{2} \quad 4 \mathrm{O}_{2}$ の動脈血 $\mathrm{O}_{2}$ 容量に対与る関係は， I 群では侹常者々ほぶ等しい分布を示すのにたい

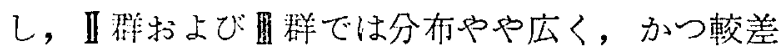
大となるむのが多い， $\mathrm{O}_{2}$ 攝取率は図 1 のごとく， 健管 $0.60 \pm 0.02$ にたいし， I 群 $0.58 \pm 0.03$, II 群 $0.64 \pm 0.03$, 目群 $0.63 \pm 0.03$ とII 圆群で高い $\mathrm{O}_{2}$

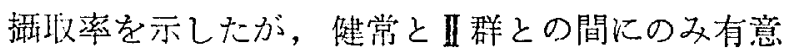
の差を認めた。

RQ 心解 RQ は僬常者 $0.89 \pm 0.03$ にたいて， I 群 $0.83 \pm 0.10$, II 群 $0.82 \pm 0.05$, 四群 $0.82 \pm 0.06$

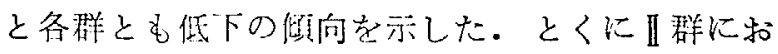
いて健常との間记有意の差があつた（図2).

pH 冠静脈血 $\mathrm{pH}$ は, つね社動脈血 $\mathrm{pH}$ 上り 低估を示すが，ての差は健常者に括いては0.04 以 内汇止る5)。I群は全例正常範围内，群では湘 定された 12 例中 4 例に最大 0.08 に達する較差の 增大, 四群においても 1 例に和いて較差の增大を 認めた（図 3).

冠靜脈血 $\mathbf{O}_{2}$ 分生 健常平均 $21.8 \pm 0.9 \mathrm{mmHg}$

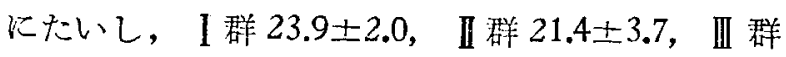
$17.9 \pm 2.4$ と【群において上舁気味, I群でや小広 く分布するが低下大なるものあり，价群では测定 された全例で明らかな $\mathrm{O}_{2}$ 分压の低下をみた（図 4).

ブドウ糖 各群ともブドウ糖動脈血訾度は $\mathrm{Ha}$ gedorn 法では 80〜130mg/dl, Somogyi 法では 食事の影響ありと思われる1例を除き 65〜110mg /d1 の間におり，この濃度において較差 0 の 1 例 を除き，つ㸚に心筋によるブドウ糖の攝取が見ら れた. Somogyi 法についての較差を見ると, 健 常平均 $6.6 \mathrm{mg} / \mathrm{dl}$ にたいし, I 群 $3.9 \mathrm{mg} / \mathrm{dl}$, II 群 $7.5 \mathrm{mg} / \mathrm{dl}$, III 群 $4.9 \mathrm{mg} / \mathrm{dl}$ となり, 健常との 間に有意の差は認められない。乙かし動脈血濃度 $80 \mathrm{mg} / \mathrm{dl}$ 以下に扎いては健常に比し攝取大なるも のあり，4mg/d1 以上の較差を示したもの】群3

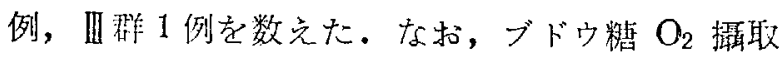
率は焦常 38.9\%にたいし，」群 $26.0 \%$, I 群 52.9 \%，四群 $33.8 \%$ となつているが，健常および各群 相互間に有意の差は認められない（図 5).

乳酸 各群とも $\Delta \mathrm{L}$ の減少を認め, 健常 $3.99 \mathrm{mg}$ /dl にたいし， I 群 $1.98 \mathrm{mg} / \mathrm{d}$, II 群 $2.30 \mathrm{mg} / \mathrm{d}$, III群 $2.48 \mathrm{mg} / \mathrm{d} 1$ と減少している。亦大乳酸攝取 率比として比警すると，図6のごとく」磼 $73.2 \%$, II 群 59.6\%，四群 $66.7 \%$ ととれぞれ健常に比し有

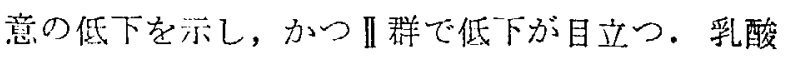
$\mathrm{O}_{2}$ 攝取棉もとれぞれ $18.6 \% ， 17.8 \% ， 17.1 \%$ と健

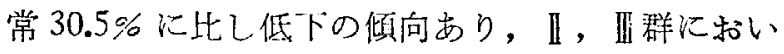
て健常と有意の差が見られた。

焦酸 $\Delta \mathrm{P}$ は备群とも健常に比し少であつたが,

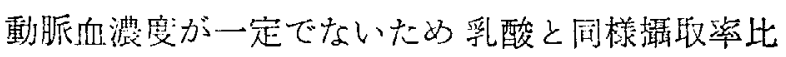
をとると图 7 のごとく，I群 69.8\%，II群 64.0\%， 㸪群 70.7\% と，いずれも健常と有意の差をもつて 低下を沶した。焦酸に扔いても，また】群に和け る低下が大と站る傾向が見られた。

I群をさらに平均血压の筒さと，心電图上 ST, 厂变化の程度にかんし；天の成績を分析してみる

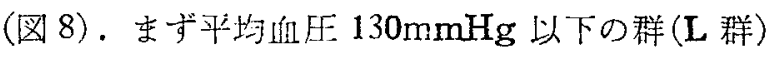

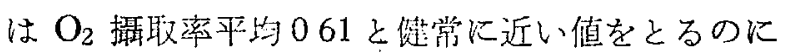
たいし， $130 \mathrm{mmHg}$ 以上の群 (H 群)は0.67 と明 らかに上舁を示し，乳酸，焦酸攝取率比も前者が それぞれ64.6\%，86.0\%なるにたいし，後者は 53.1 $\%, 37.6 \%$ となり，焦酸攝取率に有意の羑を認め た。

つぎに心電図変化についてみると, $\mathrm{O}_{2}$ 攝取率の 平均は土群 0.59 , 十群 0.62 , H群 0.68 之变化の程 度に応じた攝取率の上梨傾向あり，士群と甘群と の間に血玉による分類と同栐有意の差を得た。乳 酸摆取率比については一定の傾向はなかつたが， 焦酸摄取率比はそれ艺れ $88.3 \% ， 73.5 \% ， 48.7 \%$ と同様低下の傾向をみた。

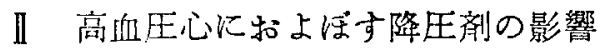

高血圧痉 3 例について 対照実験として安静無処 置による経過観察を行なつたところ，2 例におい 
Thile 1. Data on myocardial metabolism of group I in resting state

\begin{tabular}{|c|c|c|c|c|c|c|c|c|c|}
\hline$E$ & BP MBP ECGCE & & $\begin{array}{l}O_{2} \\
a-s-s / a\end{array}$ & $R Q$ & $\mid \begin{array}{cc}P H \\
a & a-s\end{array}$ & $\mathrm{PSO}_{2}$ & $\begin{array}{l}\text { Glucose } \\
\text { Ga } \triangle G G Q_{2} E P\end{array}$ & \begin{tabular}{|c|} 
Lactate \\
La $\Delta \mathrm{L} \Delta / \Delta \mathrm{LN} I \mathrm{D}_{2} \mathrm{ER}$
\end{tabular} & $\begin{array}{c}\text { Pyruvate } \\
\mathrm{Pa} \Delta \mathrm{P} \Delta \mathrm{P} / \Delta \mathrm{P}_{n} \mathrm{PO} \mathrm{P}_{2} \mathrm{ER}\end{array}$ \\
\hline $50 \hat{\delta}$ & $150 / 93 \quad 112-\#$ & 16.89 & 9.730 .58 & 1.00 & -- & - & $101^{*} 9^{*} 69.5$ & $4.08 \quad 1.9299 \quad 14.8$ & 234.0 \\
\hline $46 \delta$ & $162 / 96 / 18-+$ & 16.40 & $10.50 \quad 0.64$ & 1.05 & -- & - & $132^{*} 12^{*} 85.7$ & $5.07 \quad 2.35 \quad 107 \quad 16.8$ & 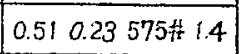 \\
\hline $49 \hat{8}$ & $158 / 84 \quad 109-+$ & 17.86 & 9.870 .55 & 1.05 & -- & - & $117^{*} 8^{*} 60.8^{* *}$ & $1.21-1.26-$ & $0.250 .05-0.3$ \\
\hline $60 \hat{\jmath}$ & $206 / 92 \quad 140-+$ & 18.28 & $10.56 \quad 0.58$ & - & - & - & $81^{*} 3^{3 *} 21.3$ & 10.66 & $\begin{array}{llll}1.35 & 0.35 & 52.2 & 2.1 \\
\end{array}$ \\
\hline $43 \hat{3}$ & $215 / 110145^{-+}$ & 15.50 & 9.330 .60 & 0.68 & 7.400 .02 & 22.5 & --- & --- & $\begin{array}{llll}1.22 & 0.16 & 28.1 & 1.1\end{array}$ \\
\hline 418 & $176 / 124141--$ & 19.30 & $10.93 \quad 0.57$ & 0.78 & 7.420 .02 & 22.0 & $\begin{array}{llll}32.6 & 1.5 & 10.3 \\
\end{array}$ & $\begin{array}{lllll}5.10 & 1.39 & 95.1 & 9.5 \\
\end{array}$ & -- \\
\hline 318 & $154 / 88 \quad 110^{-}+$ & 17.45 & 9.650 .55 & 0.63 & 3 & 24.0 & $\begin{array}{lll}76.1 & 2.6 & 20.2 \\
\end{array}$ & $\begin{array}{|llll|}6.26 & 1.24 & 38.8 & 9.6 \\
\end{array}$ & $0.540 .24250 \div 1.6$ \\
\hline 523 & $195 / 110138-+$ & 16.97 & $8.49 \quad 0.50$ & 0.77 & 7.470 .03 & 25.5 & $\begin{array}{llll}71.6 & 2.1 & 18.5 \\
\end{array}$ & --- & --- \\
\hline 154 & $170 / 120137-t$ & 18.38 & 10.710 .59 & 0.60 & $\begin{array}{lll}7.39 & 0.02\end{array}$ & 25.5 & $\begin{array}{llll}74.3 & 2.1 & 14.7 \\
\end{array}$ & $10.64 \quad 1.15 \quad 20.9 \quad 8.1$ & 0.540 .1728 \\
\hline $59 t$ & $176 / 100125--$ & 14.78 & 7.150 .48 & 0.98 & - & - & 79.00 & $8.70 \quad 6.88 \quad 145 \quad 72.0$ & $\begin{array}{llll}0.80 & 0.19 & 76 & 1.7\end{array}$ \\
\hline 166 & $166 / 110^{129-+}$ & 23.14 & 12.86 & 0.73 & 一 & - & $\begin{array}{llll}85.7 & 5.4 & 31.5 \\
\end{array}$ & $9.30 \quad 1.40 \quad 27.5 \quad 8.6$ & $0.760 .44200 \# 2.2$ \\
\hline 172 & $150 / 105^{120-+}$ & 16.79 & $11.75 \quad 0.70$ & 0.76 & & - & $80.5 \quad 7.1 \quad 45.2$ & $2.960 .56-3.6$ & --- \\
\hline 581 & $174 / 96 \quad 122-+$ & 16.36 & 66 & 0.95 & - & - & $84.8 \quad 9.7 \quad 67.5$ & $\begin{array}{llll}6.53 & 1.57 & 47.0 & 10.9\end{array}$ & $0.67 \quad 0.21 \quad 148 \# 1.3$ \\
\hline 49 & & 17.5 & $\begin{array}{r}10.18 \quad 0.58 \\
\pm 0.03\end{array}$ & $\begin{array}{l}0.83 \\
\pm 0.10\end{array}$ & 743 & $\begin{array}{l}23.9 \\
\pm 2.0\end{array}$ & $\begin{array}{r}79.3 \quad 3.926 .0 \\
\pm 3.2 \pm 20.7\end{array}$ & $\begin{array}{r}6.411 .9873 .218 .6 \\
\pm 33.4 \pm 16.3 \\
\end{array}$ & $\begin{array}{rrr}0.78 & 0.2670 .0 & 1.7 \\
\pm 65.1 & \pm 0.3 \\
\end{array}$ \\
\hline
\end{tabular}

B.P. : blood pressure $(\mathrm{mmHg})$

M.B.P. : mean blood pressure $(\mathrm{mmHg})$

E.C.G. : electrocardiogramm

C.E. : cardiac enlargement

$\mathrm{O}_{2} \mathrm{a}$ : oxygen content of arterial blood (vol\%)

$\mathrm{O}_{2} \mathrm{a}-\mathrm{s}:$ myocardial oxygen extraction

$\mathrm{O}_{2} \mathrm{a}-\mathrm{s} / \mathrm{a}:$ myocardial oxygen extraction coefficient

$\mathrm{RQ} \quad$ : myocardial respiratory quotient

$\mathrm{pHa}:$ arterial blood $\mathrm{pH}$

$\mathrm{pHa}-\mathrm{s}$ : coronary arterio-venous difference of $\mathrm{pH}$

$\mathrm{PsO}_{2}$ : oxygen partial pressure of coronary venous blood ( $\mathrm{mmHg}$ )

$\mathrm{Ga}$ : arterial glucose concentration ( $\mathrm{mg} / \mathrm{dl}$ )

$\Delta \mathrm{G}$ : coronary arterio-venous glucose difference $(\mathrm{mg} / \mathrm{dl})$

$\mathrm{GO}_{2} \mathrm{ER}$ : myocardial glucose $\mathrm{O}_{2}$ extraction ratio (\%)

$\mathrm{La}$ : arterial lactate concentration ( $\mathrm{mg} / \mathrm{dl})$

$\Delta \mathrm{L} \quad$ : coronary arterio-venous lactate difference $(\mathrm{mg} / \mathrm{dl})$

$\Delta \mathrm{L} / \Delta \mathrm{LN}$ : myocardial lactate extraction coefficient ratio (\%)

$\mathrm{LO}_{2} \mathrm{ER}$ : myocardial lactate $\mathrm{O}_{2}$ extraction ratio (\%)

$\mathrm{Pa}$ : arterial pyruvate concentration $(\mathrm{mg} / \mathrm{dl})$

$\Delta \mathrm{P} \quad$ : coronary arterio-venous pyruvate difference $(\mathrm{mg} / \mathrm{dl})$

$\Delta \mathrm{P} / \Delta \mathrm{PN}:$ myocardial pyruvate extraction coefficient ratio (\%)

$\mathrm{PO}_{2} \mathrm{ER}$ : myocardial pyruvate $\mathrm{O}_{2}$ extraction ratio (\%)

\# $\quad$ : omitted in calculating the average value because of being outside of rejection limits.

* : : omitted in calculating the average value because the data measured by Hagedorn-Jansen's method 
Table 2. Data on myocardial metabolism of group II in resting state

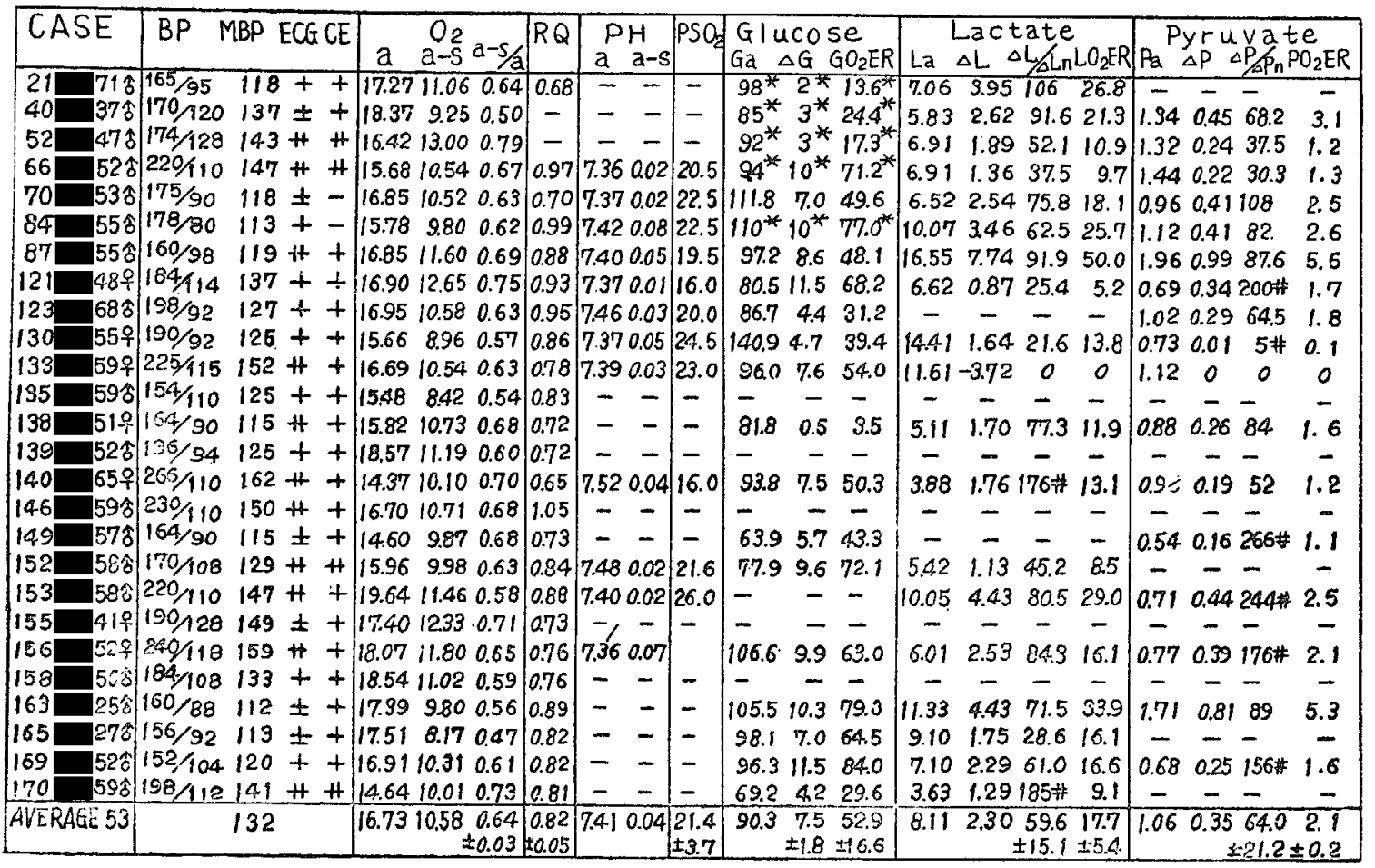

Table 3. Data on myocardial metabolism of group III in resting state

\begin{tabular}{|c|c|c|c|c|c|c|c|c|}
\hline$\overline{C A}$ & $B P$ MBP ECG CE & $\begin{array}{cc}\mathrm{O}_{2} \\
a & a-5\end{array}$ & $R \cdot Q$ & $\begin{array}{ll}\mathrm{PH} \\
\mathrm{a} & \mathrm{a}-\mathrm{S}\end{array}$ & $\mathrm{PSO}_{2}$ & 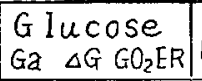 & $\begin{array}{c}\text { Lactate } \\
\mathrm{La} \Delta \mathrm{L} \Delta \mathrm{L} / \Delta \mathrm{Ln}_{\mathrm{n}} \mathrm{LO}_{2} \mathrm{ER}\end{array}$ & $\begin{array}{c}\text { Pyruvate } \\
\mathrm{Pa} \triangle \mathrm{P} \triangle \mathrm{P} / \mathrm{PP}_{\mathrm{P}} \mathrm{PO}_{2} \mathrm{EP}\end{array}$ \\
\hline 5 5수 & $138 / 7093+-$ & $20.70 \quad 13.26 \quad 0.64$ & 0.87 & -- & - & $121^{*} 5^{*} 28.3^{*}$ & 7.832 .816 & $\begin{array}{lllll}0.96 & 0.33 & 82.5 & 1.6 \\
\end{array}$ \\
\hline 411 & $128 / 8096 \pm-$ & $\left.\begin{array}{llll}19.87 & 12.09 & 0.61\end{array}\right)$ & - & - & 一 & $76^{*}-7^{*} 0^{*}$ & $\begin{array}{llll}9.38 & 2.87 & 55.9 & 17.9\end{array}$ & $47.7 \quad 2.3$ \\
\hline $49 \hat{0}$ & $130 / 90103+4$ & $18.08 \quad 11.85 \quad 0.66$ & - & - & - & $133^{*} 3^{*} 18.9^{*}$ & $\begin{array}{lllll}7.25 & 3.64 & 88.8 & 23.1\end{array}$ & $\begin{array}{lllll}1.09 & 0.33 & 68.8 & 1.8 \\
\end{array}$ \\
\hline 89 & $118 / 5677 \mathrm{H}+$ & $16.6711 .04 \quad 0.66$ & 0.71 & 7.360 .03 & 17.0 & $94.53 .2 \quad 21.1$ & $\begin{array}{llll}5.28 & 2.89 & 121 & 19.9 \\
\end{array}$ & $\begin{array}{llll}1.14 & 0.45 & 88.2 & 2.6 \\
\end{array}$ \\
\hline 117 & $150 / 80103 \pm-$ & $\begin{array}{llll}17.39 & 12.14 & 0.70\end{array}$ & 0.88 & $\begin{array}{llll}7.37 & 0.03\end{array}$ & 20.0 & $89.5 \quad 4.0 \quad 24.8$ & $10.915 .70 \quad 95.135 .3$ & $\begin{array}{llll}1.65 & 0.66 & 74.2 & 3.5\end{array}$ \\
\hline 63시 & $128 / 8096 \pm+$ & $\begin{array}{llll}16.35 & 11.85 & 0.73\end{array}$ & 0.78 & 0.06 & 16.0 & $\begin{array}{llll}76.9 & 4.3 & 27.3 \\
\end{array}$ & 7.823 .5683$. & $0.670 .22138 \# 1.3$ \\
\hline |491 & $130 / 7593 \pm+$ & $\begin{array}{llll}16.98 & 11.56 & 0.68\end{array}$ & 0.74 & 7.420 .03 & 18.5 & $102.5 \quad 3.2 \quad 21.4$ & .86 & $1130.6 \quad 0.6$ \\
\hline 509 & $138 / 90106 \pm-$ & $\begin{array}{llll}16.77 & 10.20 & 0.61\end{array}$ & 0.70 & -- & - & $82.5 \quad 0.5 \quad 3.7$ & $4.91 \quad 0.83 \quad 39.6 \quad 6.1$ & $0.450 .13-$ \\
\hline 197 & $118 / 7589+-$ & $\begin{array}{llll}16.48 & 9.61 & 0.58 \\
\end{array}$ & 0.91 & - & - & $-\quad-$ & ---- & $-\quad-$ \\
\hline 159 & $122 / 7591 \pm+$ & $\begin{array}{llll}18.17 & 10.57 & 0.58\end{array}$ & 0.97 & & - & - & --- & - \\
\hline 3 3it & $128 / 7089+-$ & 20.94 & 0.79 & -- & - & $98.5 \quad 3.7 \quad 24.4$ & $7.44 \quad 1.9248 .0 \quad 12.5$ & $0.890 .51166 \# 2.8$ \\
\hline 162 & $112 / 68.83+t$ & $\begin{array}{lll}17.38 & 10.18 & 0.59\end{array}$ & 0.76 & - & - & $70.0 \quad 3.0 \quad 21.1$ & $4.90 \quad 1.00 \quad 47.6 \quad 7.0$ & $0.59-0.01$-\# 0 \\
\hline 171 & $100 / 5872+-$ & $\begin{array}{llll}5.14 & 8.68 & 0.57\end{array}$ & 0.79 & - & - & $\begin{array}{llll}85.9 & 4.4 & 38.0\end{array}$ & $\begin{array}{llll}7.96 & 1.06 & 24.6 & 9.2 \\
\end{array}$ & - \\
\hline 98 & $16488100+-$ & $\begin{array}{llll}4.87 & 9.83 & 0.66\end{array}$ & 0.93 & & - & $99.2 \quad 16.0 \quad 122$ & $\begin{array}{llll}9.05 & 1.65 & 18.2 & 12.4 \\
\end{array}$ & $0.90 \quad 0.33 \quad 103 \quad 2.1$ \\
\hline$E 53$ & 93 & 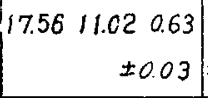 & $\begin{array}{l}0.82 \\
\pm 0.06\end{array} \mid$ & 7.410 .04 & $\begin{array}{l}17.9 \\
\pm 2.4\end{array}$ & $\begin{array}{r}88.84 .733 .8 \\
\pm 3.4 \pm 26.4\end{array}$ & $\begin{array}{r}7.282 .4866 .716 .2 \\
\pm 21.1 \pm 5.2 \\
\end{array}$ & $\begin{array}{r}0.970 .32 \quad 70.7 \quad 1.8 \\
\pm 22.8 \pm 0.22 \\
\end{array}$ \\
\hline
\end{tabular}


Fig. 1.

Myocardial oxygen extraction coefficient

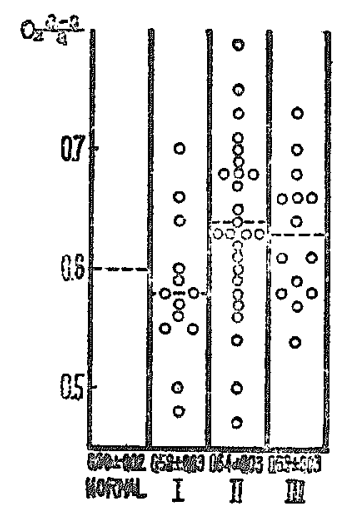

Fig. 4.

Oxygen partial pressure of coronary venous blood

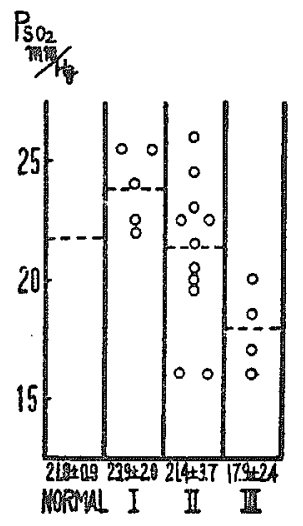

Fig. 7.

Myocardial pyruvate extraction coefficient ratio

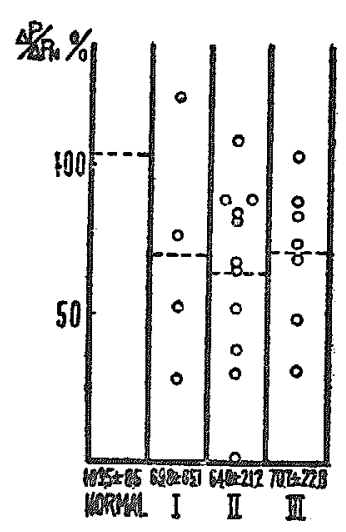

Fig. 2.

Myocardial respiratory quotient

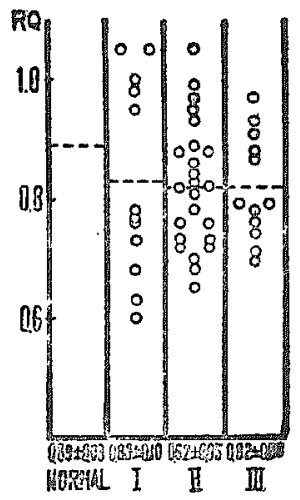

Fig. 5.

The relationship between arterial glucose concentration and myocardial glucose extraction (Somogyi's method)

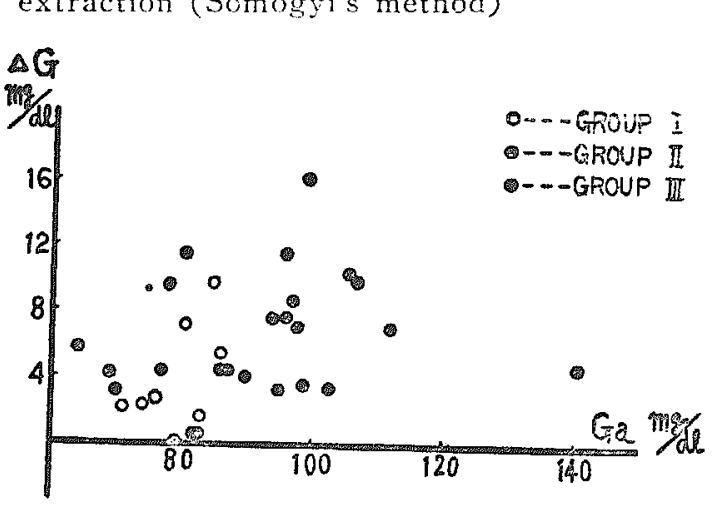

Fig. 3.

The relationship between arterial blood $\mathrm{pH}$ and coronary venous blood $\mathrm{pH}$

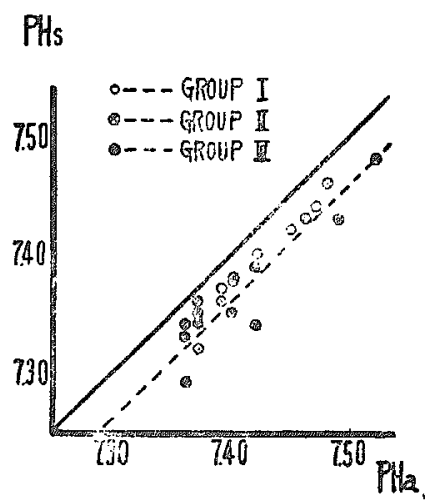

Fig. 6.

Myocardial lactate extra. ction coefficient ratio

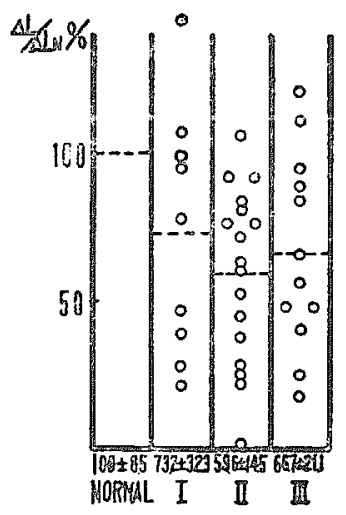

Fig. 8.

Classification of group II by Ecg findings Classification of group II by mean blood pressure
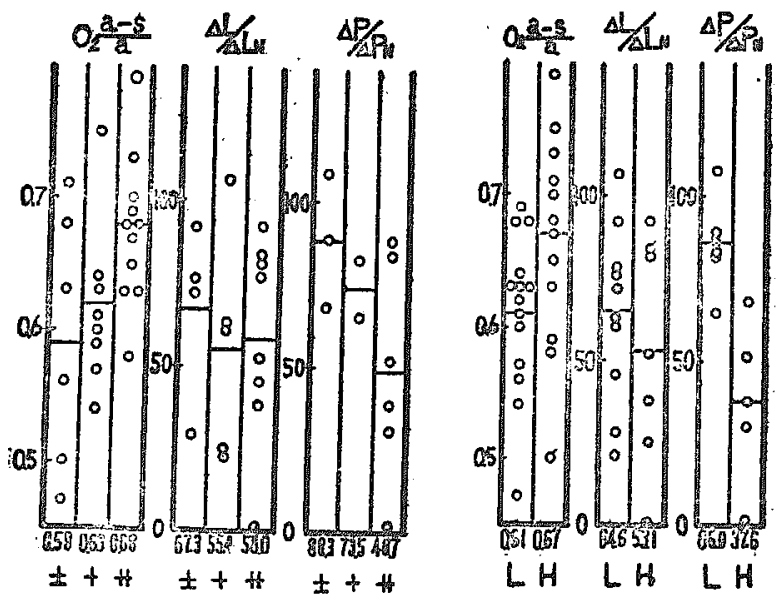
て30分の経渦中, 血生汪と九ど不変汇終始し,

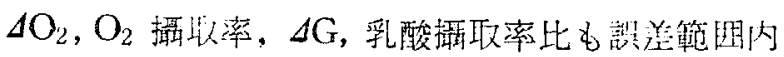
の花動起示したに過き就かつたにたいし，他の1 例で経過中平均血正 $30 \mathrm{mmHg}$ の血压下降去 ᄂ, $\Delta \mathrm{O}_{2}$ 減少, $\mathrm{O}_{2}$ 攝耿率低下, $\Delta \mathrm{G}$ 減少, 孚酸

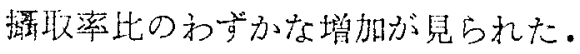

つぎに降止刜としてへキサメトニウム（メトブ ロミン)，ハイドララジン(アブレゾリン)を使用 して。泟者々も生食水に溶かし，極めて徐子に 15 机い6 60 分要して静脈内注入，近圧下降後 10 分以上大凡一定の值が保たれたさい、剆定を行 はつた。
ヘキサメトニゥム $\left(\mathrm{C}_{6}\right)$ は6 例について行い 10 ２5mg を静洁，平均血压の下降注平均 $14.2 \mathrm{~mm}$ $\mathrm{Hg}$ でむつた。 $\Delta \mathrm{O}_{2}$ は增大 1 , 不变 2 , 減少 $3, \mathrm{O}_{2}$

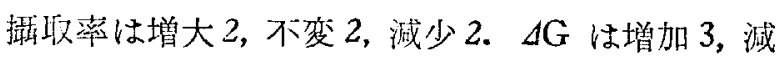
少 3 で一定の傾向なく， $\Delta \mathrm{L}$ は 1 例減少した他 4 例で增加, 乳酸攝取率比は $4 \mathrm{mg} / \mathrm{d} 1$ 以上の動脈血 䟴度を示した 3 例全部に增大をみた。焦酸でも同

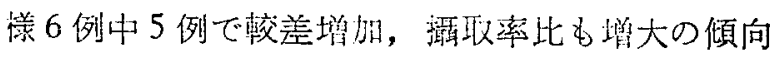
を示した（第 5 丧）。

ハイドララジン (Hy) は4 例について行い 7.5 $\sim 14 \mathrm{mg}$ 劣静注, 平均血王は平均 $15 \mathrm{mmHg}$ の下 降を示した。このさい，とくに頻脈に注意し，1

Table 4. Data on myocardial metabolism of control cases

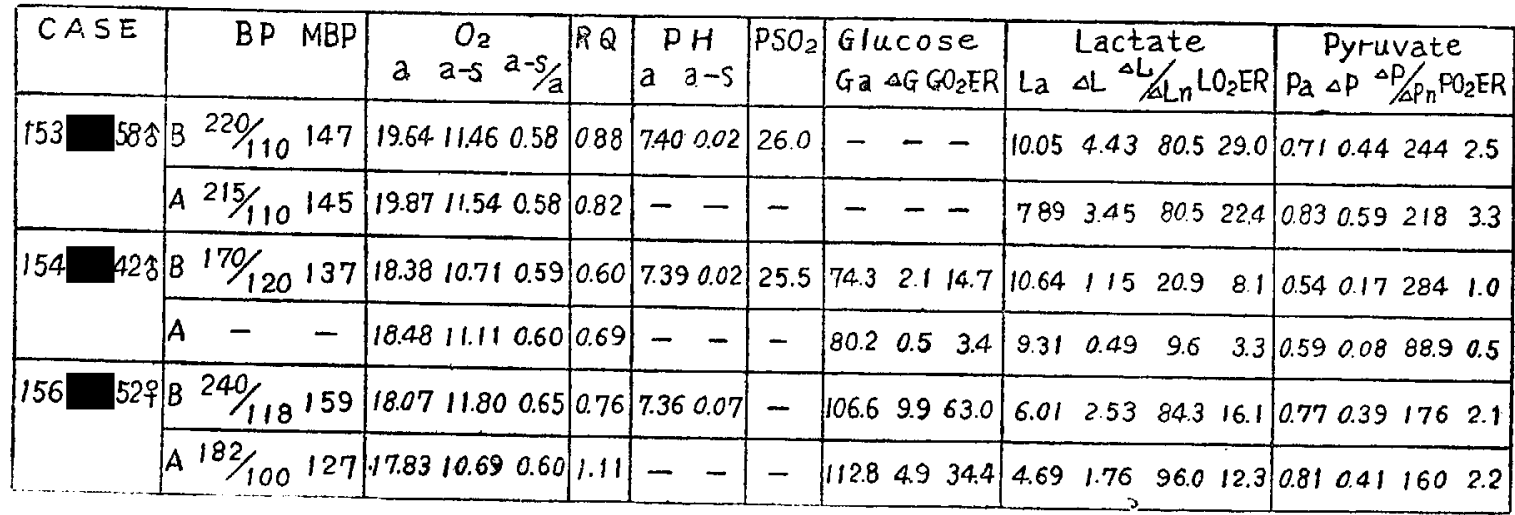

B: Before A: After

Table 5. Effects of hexamethonium on myocardial metabolism

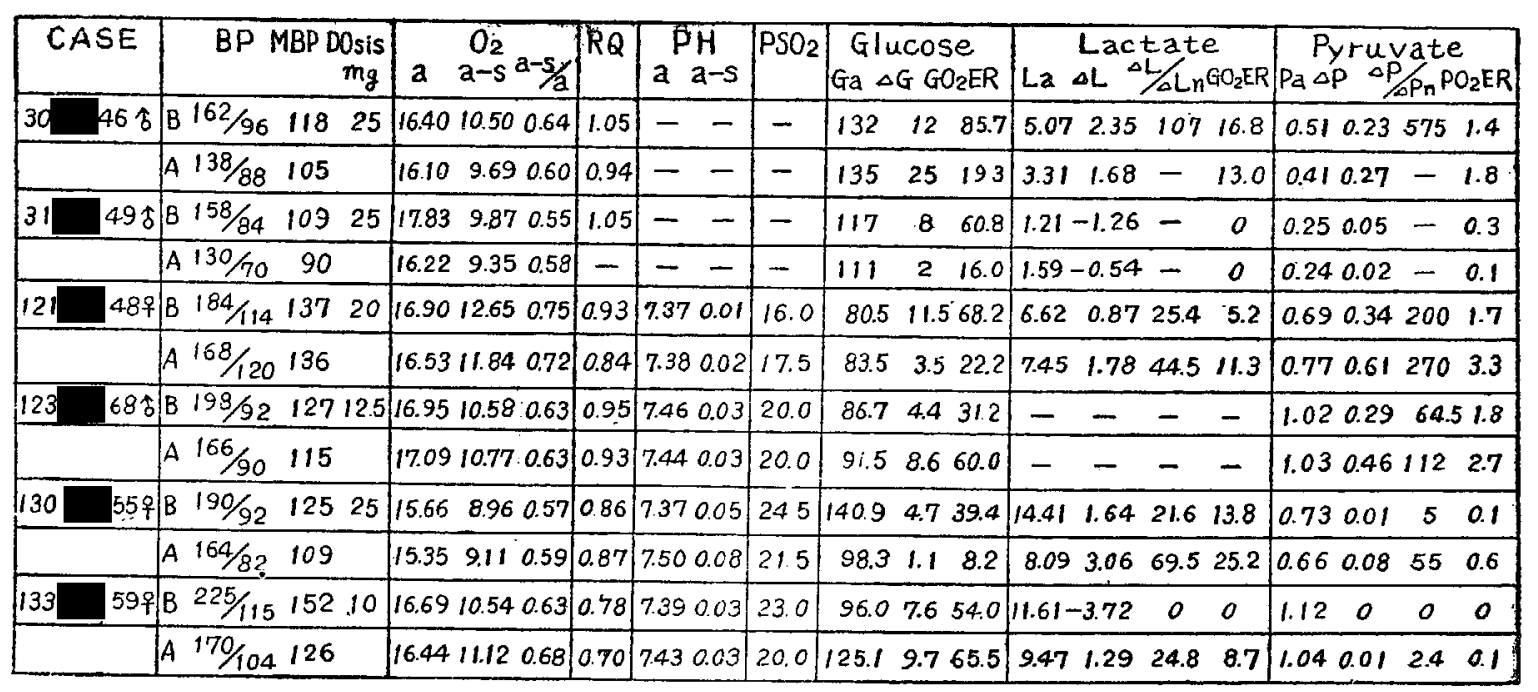

B: Before A: After 
Table 6. Effects of h $\because$ dralazine on myocardial metabolism

\begin{tabular}{|c|c|c|c|c|c|c|c|c|}
\hline$\overline{C A S E}$ & $\begin{array}{r}\text { BP MBP Dosis } \\
\mathrm{mg}\end{array}$ & a $\begin{array}{ccc}\mathrm{O}_{2} & \\
\mathrm{a}-\mathrm{s} & \mathrm{a}-\mathrm{s} / \mathrm{a}\end{array}$ & $R Q$ & \begin{tabular}{|cc}
$\mathrm{PH}$ \\
$\mathrm{a}$ & $\mathrm{a}-\mathrm{S}$ \\
\end{tabular} & $\mathrm{PSO}_{2}$ & \begin{tabular}{|c|} 
Glucose \\
$G a \Delta G \quad G O_{2} E R$
\end{tabular} & $\begin{array}{c}\text { Lactate } \\
\mathrm{La} \Delta \mathrm{L} \Delta \mathrm{L} / \Delta \mathrm{Ln} \mathrm{LO}_{2} \mathrm{ER}\end{array}$ & $\begin{array}{ll} & \text { Pyruvate } \\
\mathrm{Pa} & \Delta \mathrm{P} \Delta \mathrm{P} / \Delta \mathrm{P}_{\mathrm{n}} \mathrm{PO}_{2} \mathrm{ER}\end{array}$ \\
\hline $65 q$ & $B 266 / 110^{162} 10$ & 14.3710 .100 .70 & 0.65 & $\left|\begin{array}{ll}7.52 & 0.04\end{array}\right|$ & 16.0 & $\begin{array}{lll}93.8 & 7.5 & 50.3\end{array}$ & $3.88 \quad 1.76 \quad 176$ 标 13.1 & $\begin{array}{llll}0.96 & 0.19 & 52 & 1.2\end{array}$ \\
\hline & A $206 / 100^{135}$ & 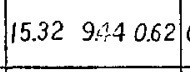 & 0.987 & 7.530 .04 & 19.0 & $\left|\begin{array}{lll}93.8 & 7.0 & 55.6\end{array}\right|$ & $3.621 .24188 \# 9.8$ & -0.02 \\
\hline 148 & $B^{154} / 10011014$ & $\left|\begin{array}{lll}17.45 & 9.65 & 0.55\end{array}\right|$ & $0.63 \mid$ & $\left|\begin{array}{lll}7.45 & 0.03\end{array}\right|$ & 25.5 & $\left|\begin{array}{lll}76.1 & 2.6 & 20.2\end{array}\right|$ & $6.26 \quad 1.24 \quad 38.8 \quad 9.6$ & $25 C \# 1.6$ \\
\hline & $A^{148 / 80} 103$ & $\mid \begin{array}{lll}18.11 & 8.49 & 0.47\end{array}$ & 0.53 & $\begin{array}{ll}7.45 & 0.02\end{array}$ & 24.5 & $\left|\begin{array}{lll}75.6 & 2.6 & 23.0\end{array}\right|$ & $\begin{array}{llll}5.14 & 0.94 & 42.8 & 8.3\end{array}$ & $\begin{array}{llll}0.72 & 0.14 & 74 & 1.0\end{array}$ \\
\hline 155 & $B^{190 / 128} \quad 1497.5$ & 174012.330 .71 & 0.73 & - & - & $-\quad-$ & $-\quad-$ & - \\
\hline & A $172 / 110131$ & 17.4011 .270 .65 & 0.86 & - & - & - & - & - \\
\hline 163 & 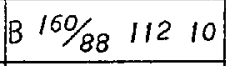 & $\mid \begin{array}{lll}17.39 & 9.80 & 0.56\end{array}$ & 0.89 & - & - & $\begin{array}{lll}105.5 & 10.3 & 79.0\end{array}$ & $11.334 .43 \quad 71.533 .9$ & $1.71 \quad 0.81 \quad 89$ \\
\hline & A $164 / 72 \quad 103$ & $\left|\begin{array}{lll}17.82 & 8.32 & 0.47\end{array}\right|$ & 0.76 & $-\quad-$ & - & $109.9-1.10$ & 13.424 .7967 .248 .1 & $\begin{array}{llll}1.93 & 0.68 & 64 & 5.2\end{array}$ \\
\hline
\end{tabular}
B: Before
A: After

Fig. 9. Effects of antihypertensive agents on myocardial metabolism

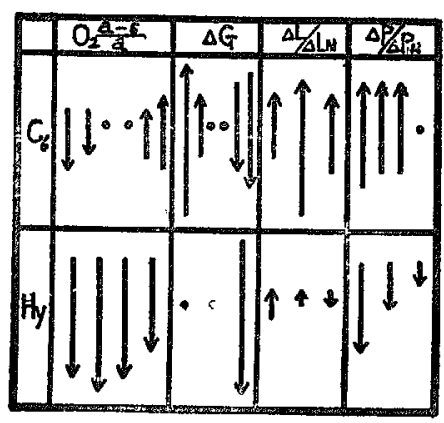

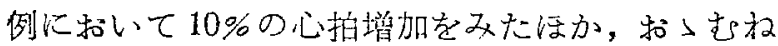
代装に止めた。 $\Delta \mathrm{O}_{2}, \mathrm{O}_{2}$ 㨨取率は全例減少， $\Delta \mathrm{G}$

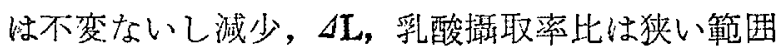
での増減を示し，焦酸は全例で較差特よび攝取率 比の低下をみた（第6表，図9）。

\section{考案}

\section{I安静時心能代謝}

高血王心および冠颃化心の心筋代謝を論ずるに らたつて，李ず本䜽文で取报われた症例の分類に つて少し述心゙る必要がある。蹦床的に心筋血流 低下を落す一つの目宾として心電図上ST 低下,

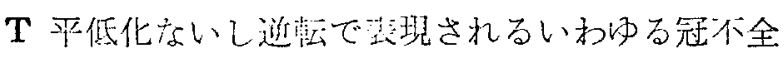

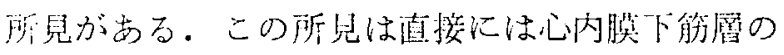

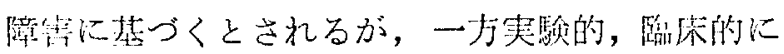

これが心筋血流低下により招来されることを示す

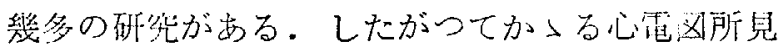
を示す高仰平患者は，健常者あるいは心電困所睍 に買常を認めない高血生患者之心籍代谢に打い

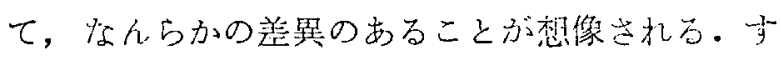
なわち|群は心仕事量增大し，乙の結桨心箱は肥 大し，酸素需要量は当然，高玉つた状㳳にdるが 6)，少なくとも心霞図を目安とした心筋 Hypoxia は䛑められない高血圧症であり，【I群は高具是の 程度，持続期間等に関連して心筋肥大ないし元動

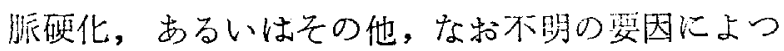
て心電図上種々の程度の ST, $\mathrm{T}$ の变化定現わし た症例である。さらに四群は高血王なく，心電図 上の变化は主として冠動脈硬化に基つくと考兄ら れる症例である。な抗この四群には運動真荷によ り初めて ST 低下ないし狭心症を起す症例も含ま れているが，これらは少なくとも安静時には冠不 全の症状のはつきりしない例である。

さて心仕事量增加に伴な弓心笳酸素消費量の增 大，および低酸素奂荷による心筋 Hypoxia に対 応する冠血流量の調節的增大については, Lombardo 7), Hackel 8), Allela 9) 等の記述があるが，

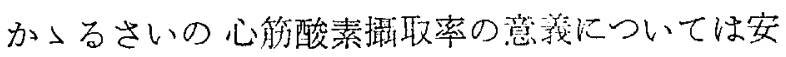
田 10）の詇述するごとく， その上䒜が酸瑟供給量 の不足を示するのとして，とくに汪四される。い 
ま各羘について酸素攝敢摔を比較すると，心電図 上買常所見のないI群では正常值を示すのにたい し，高血压および冠不全所睍を伴なう】群では健 常 0.60 汇たいし，0.64 と有意の上算を示し，また 冠不全所兒あるも高血圧を認めない四群では両者 の中阔に位する。こ机は臨床的に心筋の Hypoxia と日される心電図の冠不全所兒，あるいは運動狭 心症状を有する患者化酸素供給の不足あることを 凉すのであり，とくに高血压により心仕事量の 增加しているII 群汇著明なこと汢與味深い。か子 る事実を裏づけるものとして心㬳酸素分圧の成績 がある、すなわち酸素㩑取率の增加しているII， III 群で酸素分任の低下する症例が認められたが， これは心筇 Hypox'a をより直接的に示寸所見々

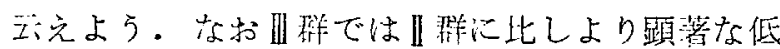
トが見られたが，これは沙群で酸素分圧の湘定さ れた例が此較的酸素攝收率の高い例であつたこと による上思われ， II 䃑より四群の方が Hypoxia

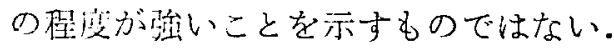

冠動静派洫 $\mathrm{pH}$ 校差については】群で $1 / 3$ 例に

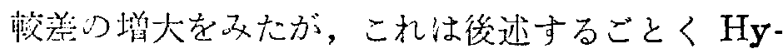

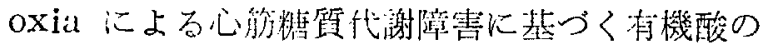

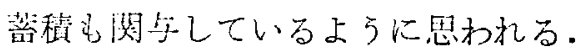

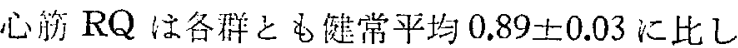

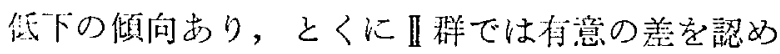
た， RQ の低下は主として脂肪酸，ヶトン体の燃 焼增加によるものと考兄られ，Gocdale ${ }^{11) ~ は イ ~ 又 ~}$ の飢餓試験で $R Q$ の藷明な低下をみている。しか し不全心に $R Q$ 低下傾向むり12)，さらに低酸素負 荷に上り $\mathrm{RQ}$ の低下をみることは13)，結買供給 の不足によるとのみは断定出来ず，心筋 Hypoxia によるコカルボキシラーゼの破壊が焦酸の酸化を

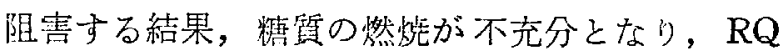
を低下せしめるのかも知れない，と沈く，これ ら高血厈心执よび冠硬化心で見られる $R Q$ の低下 は糖質代謝障害の存在を瞕示するものと思われ 当.

つぎに絬質代謝に目を転じてみると，まずブド ウ糖の心笳による攝取は異諭のないところである
が，動脈血濃度と較差との関係についてはかなら ずしも意見の一致をみない，Bing 14) は上卜にお いてブドウ糖較差は動脈血濃度の图数であり，80 $\mathrm{mg} / \mathrm{dl}$ 以下の時は $4 \mathrm{mg}$ 以下の較差を示すに過き ないが，洹度の上年に伴ない急速に較差を增大し $110 \mathrm{mg} / \mathrm{dl}$ におよんで，その最大值に達すると述 ベ, Goodale 11) はイスに招にて 60mg/d より $120 \mathrm{mg} / \mathrm{dl}$ で較差は直線的に增加し，120mg/dl 以上でや〉增加の度を減じつつ $250 \mathrm{mg} / \mathrm{di} て ゙$ て最 大 $30 \mathrm{mg}$ の較垭を示寺に至るとしている。一方

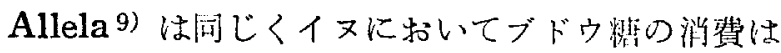

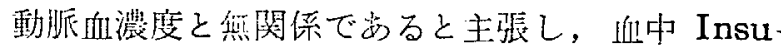
lin の量による影留を重視している。ブドウ粮然

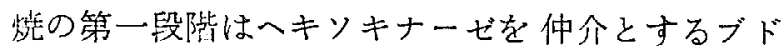
ウ糖一6一橉酸への転化であり，この反応が Insu lin で賦活されることを考穴れば, Allela の主張 理解し得るところであ万弓，高血圧心，冠硬化

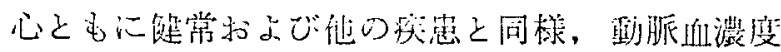
の上钭に伴ない較空增大する㖽向が見られたが， 動脈血堽度と較差との間汇一定の関倸が認められ なふつたのはこのような理由によるのであるう。

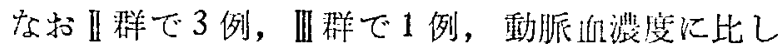
高い較差を示した. $80 \mathrm{mg} / \mathrm{d} 1$ 以下の動派血濃度に おける健常者の刘照が得られ衫かたため，その

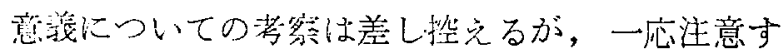
べ所見と思方れる。

乳酸にかんして露木 $\left.{ }^{3}\right)$ は各種 心疾患について 選動負荷抢上び低酸素負荷のさいの乳酸代謝の変 動追求し，薝差の減少ないし心筋よりの遊出，

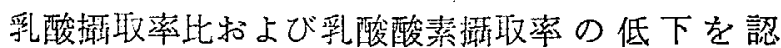
め，これが心筋 Hypoxia を共通の因子とするも のであらうと推察している。か子る権点からみる と高血圧症のみの」群で乳酸攝敢率比の低下が少 ないのにたいし，心筫 Hypoxa を招来する可能 性の大きい群での変化が大なることは露木の推 释を裏づけるものとして舆味がある。

焦酸擗取率比も健常と有意の差をるつて低下し ている. Hackel 8) はイヌで5\%の低酸素負荷を

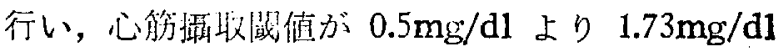


と上手し,から較差の減少することをみているが, これは動物実験による高度の低酸塐負荷の影響で あり、このままここに取扱われた症例にあてはめ ることは目難であるが，焦酸代謝異常も，また心 筋 Hy poxia によると考光させる一つの根拋とな ろう。ささに興味あるのはクェン酸の態度であつ て，協同研究者渡辺 ${ }^{15)}$ 㹥高血圧症，冠硬化症を 合めた各種疾虫でときに動脈血濃度を上迴る冠静

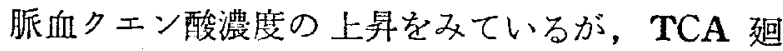
路のイソクエン酸よりオキザロコハク酸への反応 が踭気的条件で阻害される事実から，ここにるま た Hypoxia が関係しているもののよ5でする。 したがつて著者はこれら各群に程度の差こそあれ 好気的解糖過程の障害を認め，その主な原因が心 能 Hyp:xia にあることを推定するものである。 つぎに高血圧と冠硬化とが心筋代謝に扣よぽす 影響の差買について論ずる。前にも述べたごとく 】群では心仕事量は增大乙, 酸菜需要量は高方り, 当然，心筋の肥大が考えられるが，冠硬化による 酸素供給の不足は除外出来る症例である。したが つて細胞外よりの酸菜，その他，基質の供給は充 分であるが，肥大せる心筋内部に酸索报散が困難 なため限局せる Hypoxia の起る可能性がある. その結果, 細胞内部に乳酸, 焦酸の蓄積が起り，

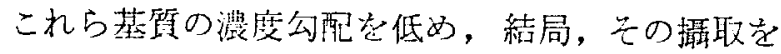
減少せしめるので山るう。これに反し，四群では 起硬化による酸素供給の制約が主となり，糖質代 謝障害はこれに伴なつて起つてくるものと思われ る. II 群はこれら二つの要素が重り合うため变化 著明で，かつ血压，心電図変化の程度沁応だ酸

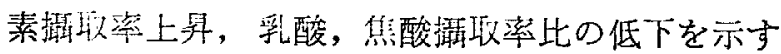
と葆总られる。

回群で荤動負荷により初めて ST 低下を来たす

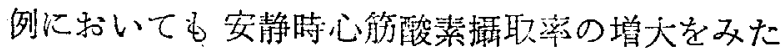
ことはここれらの例で安静時，すでに酸素代謝の 異常を示すものとして注目される。

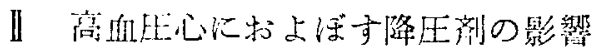

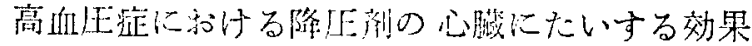

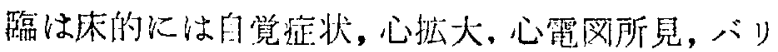

ストカルヂオグラフイー所見の改善等の報告が少 なくないが，その根拠となるべき冠循環および心 觔代謝にかんしては比較的知見に乏しい．Crumpton 16）性常イヌ执よび腎性高血生イヌに $\mathrm{C}_{6}$ を静注し，心送血量，心仕事量の減少，末梢血管 抵抗の增加, 冠血流量の減少, 酸素消費量の不変 なことを，Grob 17）は同じく $\mathrm{C}_{6}$ により高血圧患 者で心送血量, 左心仕事量, 冠血流量の減少をみ ている.Hy にかんして Rowe 18) は高佔生患者 について心仕事量, 冠血流量の增加, 冠血管抵抗 の減少, 冠静脈血酸素容量の增加および冠動静脈 血酸素較差の減少を記載している。この Roweの 成績は頻脈に伴なう心仕事量の增加があり，冠血 流量の増加についてはにわかに首肯し難いが，鞂 室に祘いて測定された例でも心送血量にたいする 冠血流量の割合が $\mathrm{C}_{6}$ では不变なのにたいし，Hy では增加しており，この両者の冠動脈にたいする 作用若干の差違のあることが推定される。蒋者 の成縖によれば降圧により酸素消費量の減少が期 待される場合， $\mathrm{C}_{6}$ ではそれが主として冠血流量の 減少により起ると思われ，安静時酸溸攝取苜の高

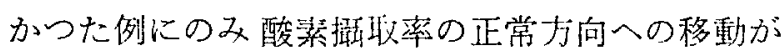
見られるのにたいし，Hy では酸素攝取率の低卜 が優先しているよ5である. Hackel 19) は脊髄森

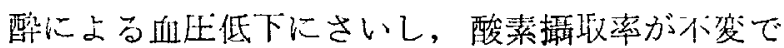
あつたことから，この場合，酸素消費量の溵少は 冠血流量の減少によつて起ると考えておう，この ことからも耐の冠動脈にたいする作用には多少 特異的なるのがあることが想像される。乳酸，焦 酸代謝についても $\mathrm{C}_{6}$ では较差增加, 嶵收率比の 上等，糖質代謝の正常方向への動きが見られる のにたいし，Hyではかつる動きが見られず，か えつて焦酸で揖取率此が減少しているのは，Hy の比較的な冠血流量の增大がある程度関与してい るのであららか。

\section{総括}

1 安静時心筇代謝 高组压症で心電図上 ST，Tにかんして所見な 
きもの13例（I群）, 同じく高血厈症にて ST 低 下， $\mathrm{T}$ 平低化ない儿逆転等冠不全所見を伴な5 。 の26 例 (II 群)，高血圧症なく安静時まなは運動 負荷後に心䨪図上冠不全所見を呈した冠硬化症 14 例（III群）計 53 例につき冠静脈カテーテル法を 実施して，これら疾患にお沙る心筋ガス括よび糖 質代謝を研究し，健常扣上び疾患相互間に扮いて つぎのごとき知見を得た。

1. I 群では冠動静脈酸素較差, 酸菜攝取菜は 正常範田内にあるにかつわらず，乳酸，焦酸攝取 率比の低下あり，糖質代謝の異常を認めた。

2. II 群ではガス代謝, 糖質代謝とも変化著明 であり, 酸素攝取率增大, 心筋 $R Q$ 低下, 冠静脈 血酸素分圧は低下せるものをみた。乳酸，焦酸攝 取率比は著明に低下し，また乳酸酸素攝取率の低 下を認めた。なお $\mathrm{pH}$ を测定した 12 例中 4 例で 冠静脈血 $\mathrm{pH}$ が異常に酸性に倾くことをみた。

3. 四群では酸素較差, 酸素骤取率增大, $\mathrm{RQ}$ 低下の傾向あり，4 例において測定された冠静脈 血酸素分圧は全例汇著明な低下をみた。乳酸代謝 の異常は】，【群の中閒に，焦酸についてはI群 に類する変化をみた。

4. 上述の賕化は主として心筋 Hypoxia によ るものであり，I群の場合は主として心笳肥大沉 より，正群の場合は主に冠動脈硬化による冠血流 の制約により招来されるものと推定した。 II 群は 両者の影響をうけ变化著明であり，かつ血圧，心 電図变化の程度に応じ代謝の罳化をみた。な打 III 群において安静時心電图に異常を呈さなかつた例 で酸素攝取率の增大を認め，心電図変化にさきだ つ心筋 Hypoxia の存在を示唆した。

\section{II高血圧心に括上ぼす降圧戍の影響}

高血圧患者 10 例にたいし，ヘキサメトニウム $\left(\mathrm{C}_{6}\right)$ ，ハイドララジン $(\mathrm{Hy})$ を静注し，その前後
に括ける心筋代謝の変動を追求した。 $\mathrm{C}_{6}$ では 6 例 中前值に招いて酸素擤取率の高かつた2 例で, Hy では4 例全部に酸素攝取率の低下をみた。一方， 糖質代謝では乳酸，焦酸攝取率比が $\mathrm{C}_{6}$ では增加 したが，Hy では不変ないし減少を示した。すな わち $\mathrm{C}_{6}$ では糖質代謝面に，Hy ではガス代謝面 に正常方向への移動をみ，この差異の生ぜるゆえ んにつき論じた。

\section{(この研究は文部省科学研究䚉の援助による。）}

\section{主要文献}

1) Bing, R.J., Hammond, M.M., Handelsman, J. C., Powers, S.R., Spencer, F.C., Eckenhof, J.E., Goodale, W.T., Hafkenschiel, J.H. \& Kety, S.S.. Am. Heart. J. 38: 1, 1949. -2) 小林 (太) 他：日本 阽术，11：845，1953. 一3) 露木：日丙会誌，46：265, 1957. -4) 厚美：日丙会瑟， 46: 1121，1957。-5) 竹內：日内会誌， $46: 1153,1957.6$-6) Allela, A., Williams, F.L., Bolene-Williams, C. \& Katz, L.N.: Am. J. Physiol., 183: 570, 1955. -7) Lomqardo, T.A., Rose, L., Tatschler, M., Tuluy, S. \& Bing, R.J.: Circulation, 7: 71, 1953. -8) Ha okel, D.B., Goodale, W.T. \& Kleinerman, J.: Circulation Research, 2: 169, 1954. -9) Allela, A., Williams, F.L., Bolene-Williams, C.\& Katz, L.N.: Am. J : Physiol., 185: 485, 1956. -10) 安田：日丙 会誌, 46:1319, 1957. -11) Goodale, W.T. \& Hackel, D.B.: Circulation Research, 1: 509, 1953. -12) 伊藤：日肉会誌，45：1020，1956. 一13）原他：螕合 臨休, 5：1670, 1956. -14) Bing, R.J., Siegel, A., Vitale, A., Balboni, F., Sparks, E., Tatschler, M., Klapper, M. \& Edward, S.: Am. J. Med. 15: 284, 1953. -15) 设辺：近日発表. -16) Crumpton, C. W., Rowe, G.G., O’Breen, G. \& Murphy, Q.R.: Circulation Research, 2: 79, 1954. -17) Grob, D., Scarborough, W.R., Kattus, A.A. \& Langford, H. G.: Circulation, 8: 352, 1953. -18) Rowe, G.G., Huston, J.H., Maxwell, G.M., Weinstein, A.B., Tuchman, H. \& Crumpton, C.W.: J. Clin. Invest. 34: 696, 1955. -19) Hackel, D.B., Sancetta, S.M. \& Kleinerman, J.: Circulation, 13: 92, 1956. 